\title{
Selective Removal of Water Generated during Hydrogenotrophic Methanation from Culture Medium Using Membrane Distillation
}

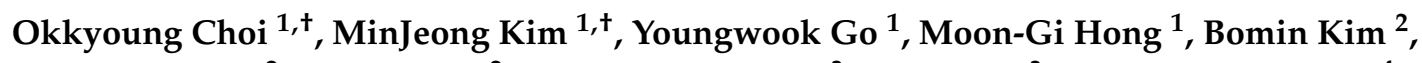 \\ Yonghyun Shin ${ }^{2}$, Sangho Lee ${ }^{2, *}$, Young Gook Kim ${ }^{3}$, Ji Sun Joo ${ }^{3}$, Byoung Seung Jeon ${ }^{4}$ and \\ Byoung-In Sang ${ }^{1, *}$ \\ 1 Department of Chemical Engineering, Hanyang University, 222 Wangsimni-ro, Seongdong-gu, Seoul 04763, \\ Korea; okgii77@hanyang.ac.kr (O.C.); mjkimsweet@hanyang.ac.kr (M.K.); youngwook@hanyang.ac.kr (Y.G.); \\ hmg3433@naver.com (M.-G.H.) \\ 2 School of Civil and Environmental Engineering, Kookmin University, 77 Jeongneung-ro, \\ Seongbuk-gu, Seoul 02707, Korea; bo6036@gmail.com (B.K.); shinyonghyun@naver.com (Y.S.) \\ 3 Korea Electric Power Research Institute, 105 Munji-ro, Yooseong-gu, Daejeon 34056, \\ Korea; younggook.kim@kepco.co.kr (Y.G.K.); jisun@kepco.co.kr (J.S.J.) \\ 4 Center for Applied Geosciences, University of Tübingen, Hölderlinstraße 12, 72074 Tübingen, \\ Germany; jbstrust@gmail.com \\ * Correspondence: sanghlee@kookmin.ac.kr (S.L.); biosang@hanyang.ac.kr (B.-I.S.) \\ + The first two authors listed share first authorship.
}

Received: 19 August 2019; Accepted: 26 October 2019; Published: 30 October 2019

check for updates

\begin{abstract}
Methane production was carried out in two different types of reactors using a thermophilic and hydrogenotrophic methanogen, Methanothermobacter sp. KEPCO-1, which converts hydrogen and carbon dioxide into methane at $60{ }^{\circ} \mathrm{C}$. The two reactors used for methane production were stirred-tank reactor (ST) and a bubble column reactor (BC), which were selected because they can provide a good comparison between the medium agitation type and gas-liquid mass transfer. The specific growth rate of KEPCO-1 in the ST and BC was $0.03 \mathrm{~h}^{-1}$ and $0.07 \mathrm{~h}^{-1}$, respectively. The methane conversion rate increased to $77.8 \mathrm{~L} / \mathrm{L} / \mathrm{d}$ in the ST and $19.8 \mathrm{~L} / \mathrm{L} / \mathrm{d}$ in the $\mathrm{BC}$. To prevent the dilution of nutrients in the medium by the water generated during the hydrogenotrophic methanation reaction, a membrane distillation (MD) process was applied to selectively remove water from the culture medium. The MD process selectively removed only water from the medium. Fouling by KEPCO-1 had a negligible effect on flux and showed a high removal performance flux of $16.3 \pm 3.1 \mathrm{~L} / \mathrm{m}^{2} / \mathrm{h}$. By operating the MD process in conjunction with the hydrogenotrophic methanation process, it is possible to prevent the dilution of the nutrients in the medium by the water generated during the methanation process, thereby maintaining stable microbial growth and methanation activity.
\end{abstract}

Keywords: power to gas; hydrogenotrophic methanogen; membrane distillation; methanation; membrane flux

\section{Introduction}

Global warming due to greenhouse gas emissions has sparked interest in reducing the world's carbon footprint. As a carbon utilization method, $\mathrm{CO}_{2}$ reduction into methane $\left(\mathrm{CH}_{4}\right)$ with hydrogen produced from electrolysis has recently emerged as a promising option to store surplus renewable electricity [1,2]. In contrast to $\mathrm{H}_{2}, \mathrm{CH}_{4}$ is good for long-term storage without additional special storage materials and is already widely used as an energy carrier in compressed natural gas, transport fuel, etc. throughout the natural gas grid $[3,4]$. In particular, biomethanation for microbial reduction of $\mathrm{CO}_{2}$ 
into $\mathrm{CH}_{4}$ with renewably produced hydrogen $\left(\mathrm{H}_{2}\right)$ is catalyzed by methanogenic archaea and operates at a lower temperature $\left(40-70{ }^{\circ} \mathrm{C}\right)$ and lower pressure $(\leq 10 \mathrm{bar})$ than chemical methanation [2].

Methanogenic archaea that produce methane using acetate (acetoclastic) or $\mathrm{CO}_{2}$ (hydrogenotrophic) are capable of thriving under extreme conditions, such as high temperatures or high salt environments [5]. The methanation rate of hydrogenotrophic methanogens was greater than that of acetoclastic methanogens [6], and among hydrogenotrophic methanogens, thermophilic hydrogenotrophic methanogens demonstrated a shorter doubling time [7] and a higher methane production rate than those of mesophilic hydrogenotrophic methanogens (Figure 1). The gas-liquid mass transfer of $\mathrm{H}_{2}$, known as the main obstacle to the successful application of biomethanation with hydrogenotrophic methanogens [8], has been improved by the use of pressurized fermenters [9] and a high stirring speed [10].

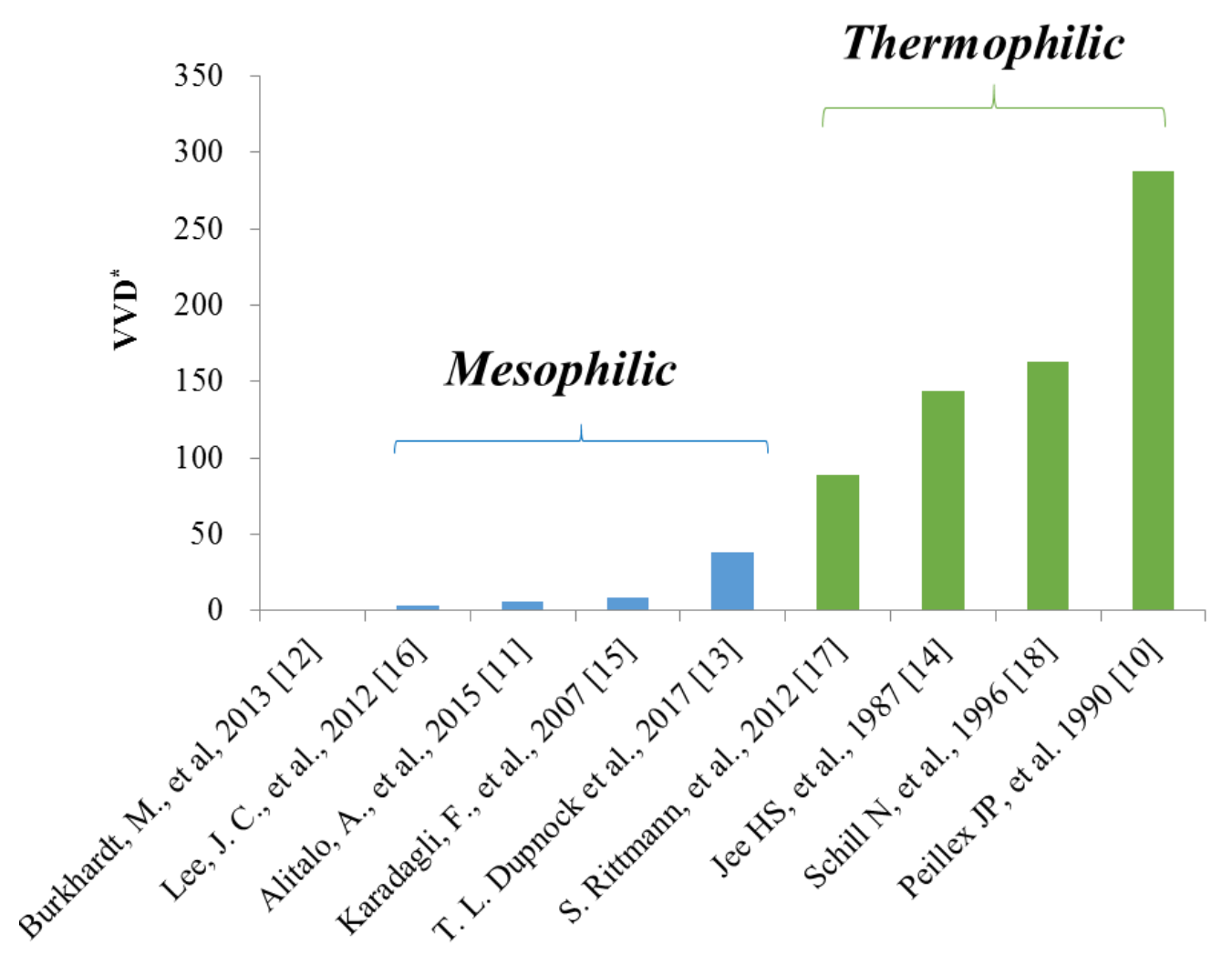

Figure 1. Comparison of the methane production rate between mesophilic and thermophilic hydrogenotrophic methanogens. VVD: Volumetric production of methane per working volume per day [10-18].

Another main obstacle is water generation during biomethanation, as shown in Equation (1) [19].

$$
4 \mathrm{H}_{2}(\mathrm{~g})+\mathrm{CO}_{2}(\mathrm{~g}) \rightarrow \mathrm{CH}_{4}(\mathrm{~g})+2 \mathrm{H}_{2} \mathrm{O}(\mathrm{l}) \Delta \mathrm{G}_{0}^{\prime}=-131 \mathrm{~kJ} / \mathrm{mol}
$$

As one mole of methane is produced, the medium volume of the fermenter is inevitably increased, and the medium is diluted by two moles of generated water. For the growth of hydrogenotrophic methanogens, $\mathrm{H}_{2}$ and $\mathrm{CO}_{2}$ are used as energy and carbon sources, and ammonium ion $\left(\mathrm{NH}_{4}{ }^{+}\right)$, hydrogen sulfide $\left(\mathrm{H}_{2} \mathrm{~S}\right)$, and other trace elements are required. In particular, the optimum concentration of $\mathrm{NH}_{4}{ }^{+}$and $\mathrm{H}_{2} \mathrm{~S}$ should be maintained to obtain the maximum methanation rate, but during biomethanation, their optimum concentrations can be diluted by the generated water. This phenomenon indicates that the development of a process to remove only the generated water from biomethanation fermenters is important for stable $\mathrm{CH}_{4}$ production with hydrogenotrophic methanogens. By discharging 
water containing very low concentrations of $\mathrm{NH}_{4}{ }^{+}$and $\mathrm{H}_{2} \mathrm{~S}$ using the water removing technology, the operation cost of wastewater treatment following the biomethanation process can be reduced.

Membrane distillation (MD) is a useful separation process for the removal of only water from the culture medium during the thermophilic methanation process. During MD, low-grade heat can be used to remove water by a vapor pressure gradient from the feed through a phase change. Direct contact membrane distillation (DCMD) condenses steam by bringing cold permeate or distillate streams into direct contact with the membrane. MD has been widely applied in desalination [20-22] and wastewater treatment [23-25]. This widespread use is due to the low probability of contamination of the MD compared to the pressure-driven process, the ability to achieve very high concentration factors, and the excellent permeation quality [26]. In particular, hydrophobic membranes only allow the passage of vapor [27].

In this study, the MD process was applied to remove the water produced during the methanation process using two different types of mixer-operated fermenters: By a stirrer (stirred tank reactor) and by a diffuser (bubble column). This is a feasibility study and our results suggested that the integrated system of biomethanation and MD could be applied to remove only water without losing nutrients in the methanation process. Thermophilic autotrophic methanation has the advantage of saving thermal energy and reducing the fouling of the MD system.

\section{Methods and Materials}

\subsection{Methanogen}

A thermophilic hydrogenotrophic methanogen, Methanothermobacter sp. KEPCO-1 (KEPCO-1), was isolated from anaerobic sludge from a local wastewater treatment plant in Seoul, Korea. The strain was stored in a $50 \%$ glycerol stock at $-80^{\circ} \mathrm{C}$ and was serially transferred from a $125 \mathrm{~mL}$ serum bottle to a 1 L Duran ${ }^{\circledR}$ bottle (Daehan Scientific Co. Ltd., Seoul, Korea) for inoculation. The bottles were filled with mixed gas $\left(\mathrm{CO}_{2}: \mathrm{H}_{2}=1: 4\right)$ and capped with a rubber stopper and an aluminum cap. ATCC medium 2133 (OSU967) was used, containing (per liter): $1 \mathrm{~g} \mathrm{NH}_{4} \mathrm{Cl}, 0.3 \mathrm{~g} \mathrm{KH}_{2} \mathrm{PO}_{4}, 0.6 \mathrm{~g} \mathrm{NaCl}, 0.1 \mathrm{~g} \mathrm{MgCl} \cdot 6 \mathrm{H}_{2} \mathrm{O}$, $0.06 \mathrm{~g} \mathrm{CaCl}_{2} \cdot 2 \mathrm{H}_{2} \mathrm{O}, 4.0 \mathrm{~g} \mathrm{NaHCO}_{3}, 0.5 \mathrm{~g} \mathrm{~L}$-cysteine. $\mathrm{HCl}, 0.5 \mathrm{~g} \mathrm{Na}_{2} \mathrm{~S} \cdot 9 \mathrm{H}_{2} \mathrm{O}$, and $10 \mathrm{~mL} \times 100$ trace elements. Trace elements contained (per $1 \mathrm{~L}$ ): $1.35 \mathrm{~g} \mathrm{FeCl}_{3} \cdot 6 \mathrm{H}_{2} \mathrm{O}, 0.1 \mathrm{~g} \mathrm{MnCl}_{3} \cdot 4 \mathrm{H}_{2} \mathrm{O}, 0.1 \mathrm{~g} \mathrm{CaCl}_{2} \cdot 6 \mathrm{H}_{2} \mathrm{O}$, $0.1 \mathrm{~g} \mathrm{ZnCl}_{2}, 0.01 \mathrm{~g} \mathrm{H}_{3} \mathrm{BO}_{3}, 1.0 \mathrm{~g} \mathrm{NaCl}, 0.15 \mathrm{~g} \mathrm{NiCl}_{2} \cdot 6 \mathrm{H}_{2} \mathrm{O}, 0.05 \mathrm{~g} \mathrm{AlCl}_{3} \cdot 6 \mathrm{H}_{2} \mathrm{O}, 24.0 \mathrm{mg} \mathrm{CoCl} 2 \cdot 6 \mathrm{H}_{2} \mathrm{O}$, $25.0 \mathrm{mg} \mathrm{CuCl} 2 \cdot 2 \mathrm{H}_{2} \mathrm{O}, 24.0 \mathrm{mg} \mathrm{Na} \mathrm{MoO}_{4} \cdot 2 \mathrm{H}_{2} \mathrm{O}$, and $26.0 \mathrm{mg} \mathrm{Na}_{2} \mathrm{SeO}_{4} \cdot 6 \mathrm{H}_{2} \mathrm{O}$. The $\mathrm{pH}$ was adjusted to 7.5 using $6 \mathrm{~N} \mathrm{NaOH}$. Methanogens were incubated at $60^{\circ} \mathrm{C}$ with shaking at $200 \mathrm{rpm}$. Two different types of thermophilic hydrogenotrophic methanation reactors were operated in the laboratory at $60^{\circ} \mathrm{C}$ for about three months while purging the mixed gas of $\mathrm{H}_{2}$ and $\mathrm{CO}_{2}$ with a volumetric ratio of 4:1.

\subsection{Methanation Reactors}

\subsubsection{Stirred-Tank Reactor (ST)}

A bioreactor (3 L, Fermentec Co. Ltd., Cheongju-si, Korea) was used as the stirred-tank reactor (Figure 2a). The overhead mixer was used with an impeller speed from $150 \mathrm{rpm}$ to $600 \mathrm{rpm}$. The working volume was $1.5 \mathrm{~L}$, and the temperature was maintained at $60 \pm 2{ }^{\circ} \mathrm{C}$ using an external heating jacket. The influent rate of mixed gases was controlled at $600 \mathrm{~mL} / \mathrm{min}\left(\mathrm{CO}_{2}: \mathrm{H}_{2}=1: 4,24 \mathrm{~h}^{-1}\right.$ inflow gas per working volume) using digital mass flow controllers (HFC-D-302B, infoRAD corp., Gyeonggi-do, Korea). The $\mathrm{pH}$ was adjusted to $7.3 \pm 0.2$ using $6 \mathrm{~N} \mathrm{NaOH}$. A mixed solution containing ammonium chloride $(200 \mathrm{~g} / \mathrm{L})$ and $\mathrm{Na}_{2} \mathrm{~S} \cdot 9 \mathrm{H}_{2} \mathrm{O}(100 \mathrm{~g} / \mathrm{L})$ was manually injected to maintain $\mathrm{NH}_{4}{ }^{+}$and sulfide concentration at $\sim 1 \mathrm{~g} / \mathrm{L}$ of $\mathrm{NH}_{4} \mathrm{Cl}$ and $0.5 \mathrm{~g} / \mathrm{L}$ of $\mathrm{Na}_{2} \mathrm{~S} \cdot 9 \mathrm{H}_{2} \mathrm{O}$ (the concentration of the medium), respectively, when the daily measurement was lower than $0.5 \mathrm{~g} / \mathrm{L}$ of ammonium chloride. 


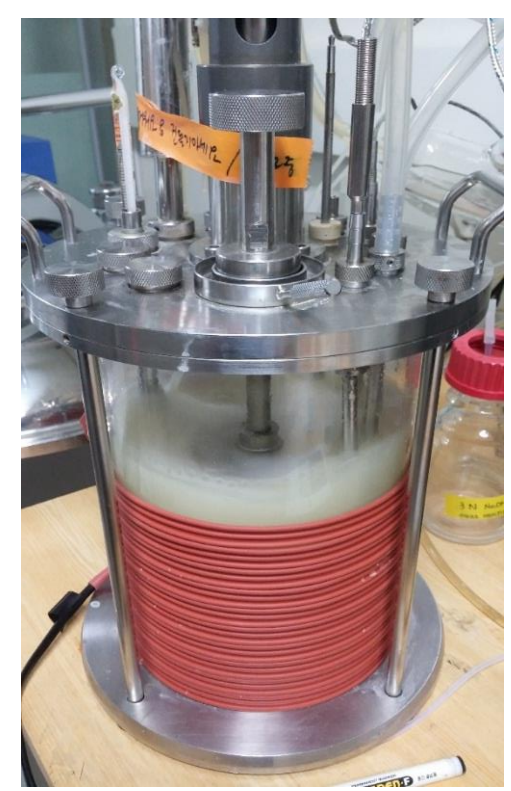

(a)

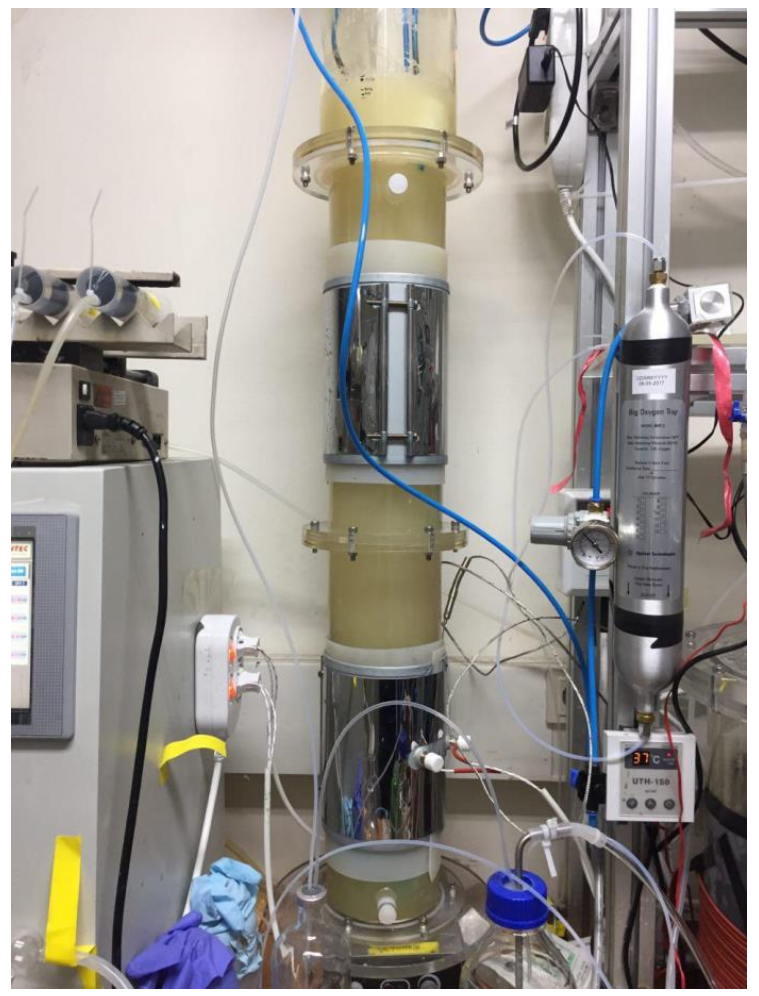

(b)

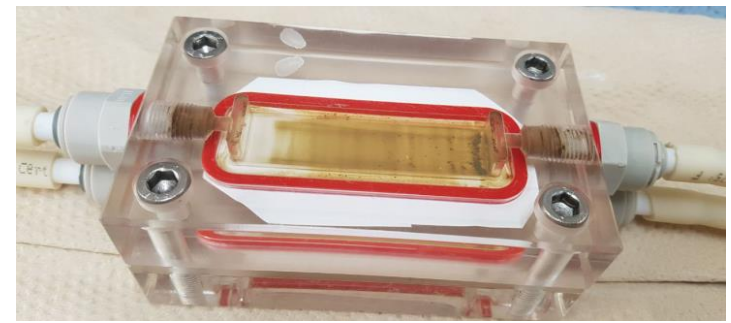

(c)

Figure 2. Images of the stirred-tank reactor (ST) (a), the bubble column reactor $(\mathrm{BC})(\mathbf{b})$, and the membrane distillation (MD) module (c). 


\subsubsection{Bubble Column (BC)}

A cylindrical reactor (15 L) was customized and prepared with polycarbonate (Figure 2b). The diameter and height were $120 \mathrm{~mm}$ and $1410 \mathrm{~mm}$, respectively. A ceramic membrane diffuser ( $25 \mathrm{~cm} \times 40 \mathrm{~mm}, 0.01-0.5 \mu \mathrm{m}$ pore size, Korea Ceramic International, Gyeonggi-do, Korea) was used as a sparger to make 100-200 $\mu \mathrm{m}$ bubbles. To support the mixing of biomass, a peristaltic pump (GT-150D, Green Tech, Gyeonggi-do, Korea) was used for circulation with $1 \mathrm{~L} / \mathrm{min}$ between the upper and lower points. The supply for ammonium and sulfide supplementation was the same as above in the ST. The working volume was $5 \mathrm{~L}$, and the influent rate of mixed gases was $140 \mathrm{~mL} / \mathrm{min}\left(\mathrm{CO}_{2}: \mathrm{H}_{2}=1: 4\right.$, $8.4 \mathrm{~h}^{-1}$ inflow gas per working volume), which was controlled using digital mass flow controllers. Ammonium was added intermittently via syringe as an $\mathrm{NH}_{4} \mathrm{Cl}$ solution when ammonia deficiency was indicated by the cell concentration.

\subsection{Membrane Distillation}

As a hydrophobic membrane, a PVDF (polyvinylidene fluoride) membrane with a pore size of $0.2 \mu \mathrm{m}$ (GVS Korea Ltd., Namyangju-si, Korea) with an effective membrane area of $0.3 \mathrm{~cm}^{2}$ was used for the MD process. The acrylic module was used and consisted of a feed compartment $\left(10 \times 6 \times 2 \mathrm{~cm}^{3}\right)$, PVDF membrane $\left(7 \times 2.5 \mathrm{~cm}^{2}\right)$ and permeate compartment $\left(10 \times 6 \times 2 \mathrm{~cm}^{3}\right)$ (Figure $\left.2 \mathrm{c}\right)$. The performance of MD was compared with feed without cells (medium) and with cells (culture solution, after growth in medium). Two types of feeds at $60^{\circ} \mathrm{C}$, i.e., fresh medium and culture solution (optical density (O.D.) at $600 \mathrm{~nm}=\sim 4$, equal to $1.6 \mathrm{~g} \mathrm{MLVSS} / \mathrm{L}$ ), were used to compare the water removal rates. To prevent cell fracture, the pump for the cell culture was a magnetic gear pump (EMS Tech, Gyeonggi-do, Korea) operated at $800 \mathrm{~mL} / \mathrm{min}$ at $60^{\circ} \mathrm{C}$, which was controlled by a heat exchanger. The permeate was anaerobically treated with distilled water and pumped with a peristaltic pump (Cole-Parmer, Vernon Hills, IL, USA) at $600 \mathrm{~mL} / \mathrm{min}$ at $20^{\circ} \mathrm{C}$, which was controlled by a low-temperature circulator (CCA-1112A, Sunileyela, Gyeonggi-do, Korea). The Reynolds numbers of feed and permeate are 3302.36 and 1171.78, respectively. The mass of the water collected by the condenser was measured by an electronic balance [28]. The conductivity was measured using an edge ${ }^{\circledR}$ multiparameter EC/TDS/salinity meter (HI2030-01, Hanna instruments, Smithfield, RI, USA) to ensure that only water, and not ions, was removed from the feed. In addition, ammonium was analyzed in the permeate to ensure that only water was removed by using a Merck RQflex reflectometer (10007723, Merck, Darmstadt, Germany).

\subsection{Monitoring and Experimental Analysis}

The methanogen concentration was measured by optical density using UV-VIS spectrophotometry (Libra S22, Biochrom, UK) at $600 \mathrm{~nm}$. Methane production was measured by GC-TCD (gas chromatography thermal-conductivity detector 7890A, Agilent, Santa Clara, CA, USA) with a Porapak Q Column (Supelco, Inc, $6 \mathrm{ft} \times 1 / 8$ in, SS, 80/100 mesh) and oven, injector, and detector temperatures of $80^{\circ} \mathrm{C}, 0^{\circ} \mathrm{C}$, and $230^{\circ} \mathrm{C}$, respectively. Gas analysis using GC-TCD was expressed as gas composition ( $\mathrm{P}_{\text {gas }}, \%$ ) using standard calibration prepared with a known gas composition sets containing $\mathrm{H}_{2}$, $\mathrm{CO}_{2}$, and $\mathrm{CH}_{4}$. The effluent gas amount (volume) decreased because of the decompression reaction $\left(4 \mathrm{H}_{2}+\mathrm{CO}_{2} \rightarrow \mathrm{CH}_{4}+2 \mathrm{H}_{2} \mathrm{O}\right)$ and can be deduced from the methane production, as shown in Equation (2). The methane production rate was calculated as VVD (volume of methane production per working volume per day), as shown in Equation (3).

$$
\begin{gathered}
\text { Effluent gas (vol.) }=\frac{\text { Influent gas (vol.) }}{1+4 \times \mathrm{P}_{\mathrm{CH}_{4}, \%}} \\
\text { Methane production rate }(\mathrm{VVD})=\frac{\text { Daily effluent gas vol. } \times \mathrm{P}_{\mathrm{CH}_{4} \%}}{\text { Working vol. in reactor }}
\end{gathered}
$$


The nitrogen concentration of ammonium was determined reflectometrically, using test strips (RQflex10, Merck, Darmstadt, Germany). The increase in conductivity due to the supplementation with nitrogen, sulfide, and base solution for $\mathrm{pH}$ control was monitored using a multiparameter EC/TDS/salinity meter (HI2030-01, Hanna Instruments, Woonsocket, RI, USA).

\section{Results and Discussion}

\subsection{Methane Production in the ST and BC}

In the ST, KEPCO-1 showed a specific growth rate of $0.035 \mathrm{~h}^{-1}$ without a lag period (Figure 3a). After the 13th day, the concentration of KEPCO-1 was not significantly changed until 37 days, and the mean VVD was $9.5 \pm 5.6$ (Figure 3a). On the 32nd day, the agitation rate was changed to $500 \mathrm{rpm}$, and both O.D. and VVD began to increase to 16.2 and 77.8, respectively (Figure 3a). Previous studies have shown that the rate of methane production was significantly enhanced when the agitation rate was increased in the reactor [10]. The intense mixing of the substrate in the gas and the biocatalyst in the liquid (gas-liquid mass transfer) increased the $\mathrm{CO}_{2}$ conversion to $\mathrm{CH}_{4}$.

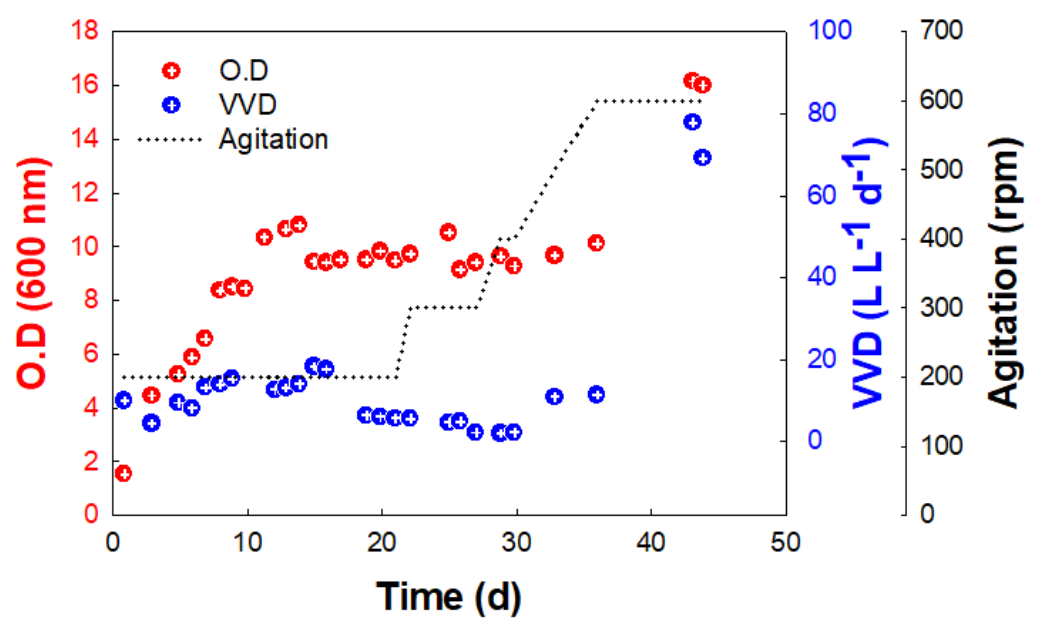

(a)

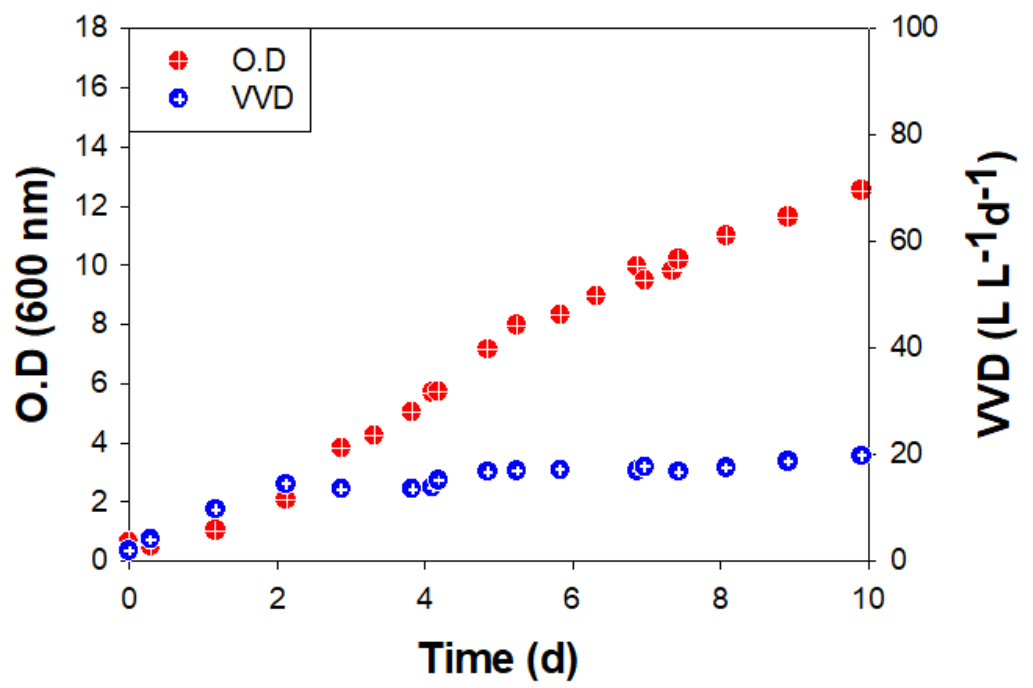

(b)

Figure 3. Growth (O.D.at $600 \mathrm{~nm}$ ) and methane production rate (VVD) of BS-9 (a) in ST and (b) $\mathrm{BC}$ reactors. 
In the BC, O.D. also increased without a lag period after 10\% inoculation at an initial O.D. $=0.63$. The maximum specific growth rate $\left(\mu_{\max }\right)$ was $0.034 \mathrm{~h}^{-1}$, and the final O.D. was 12.5 on the 10 th day (Figure $3 b$ ). The methane conversion rate was relatively stable as $\sim 20$ VVD (Figure 3b). The final O.D. was not changed after 10 days. The limit of the methane production rate (VVD) seems to be due to the low solubility of hydrogen and limitations of mass transfer, such as low mixing efficiency between cells in liquid (biocatalyst) and gas (substrate) in the BC [29,30].

VVD is dependent on the gas inflow rate, as shown in Equation (1). Previous studies have also reported that a higher gas hourly space velocity (GHSV) led to higher methane productivity (Figure 4). Compared with previous reports $[9,31]$ that show a high methane production rate at high GHSV, the methane production rate in this study showed a convincing conversion rate at low GHSV (Figure 4). The ratio of VVD versus O.D. can indicate the activity of methanogen activity as biocatalysts. Comparing the ST and BC data, it can be seen that the three-fold higher value of VVD/O.D. in the ST (4.8 vs. 1.6) was due to the GHSV value of the ST being three times larger ( 24 vs. 8.4 , Table 1 ). In addition, the agitation speed in the ST increased the ratio of VVD/O.D.

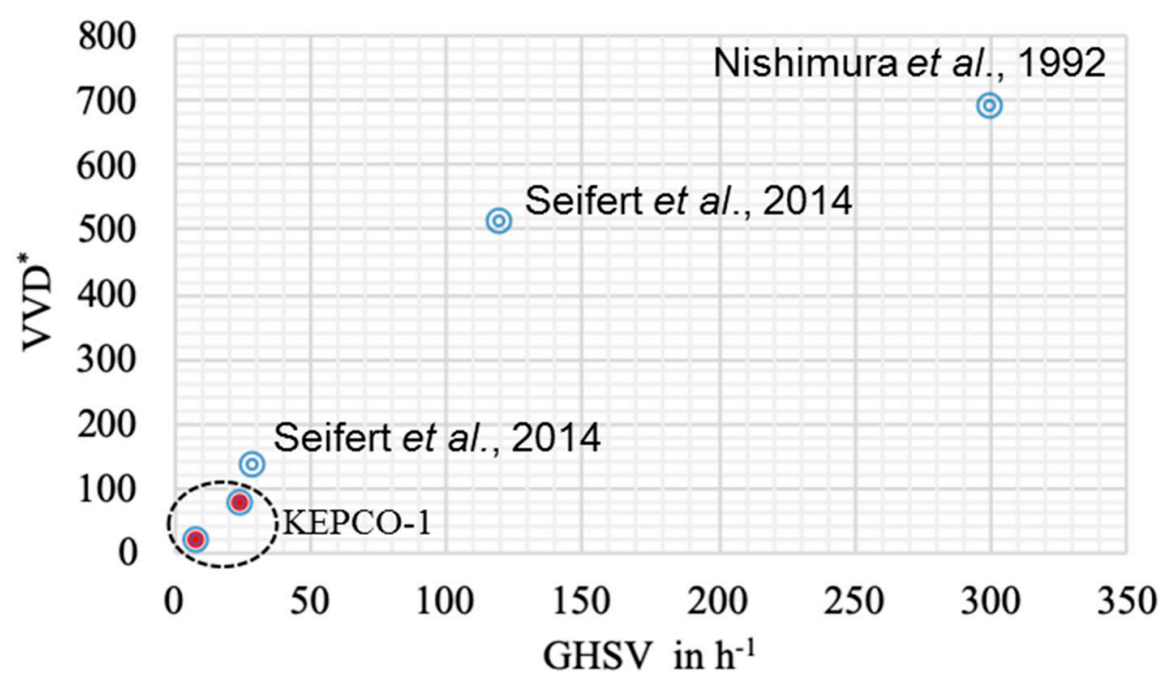

Figure 4. Comparison of the methane production rate with previous reports. The methane production rate $(*$ VVD, volume of methane per volume of reactor per day) as a function of gas hourly space velocity (GHSV).

Table 1. Comparison of operation parameters and biomethanation process between the -ST and $\mathrm{BC}$ reactors.

\begin{tabular}{|c|c|c|}
\hline Operation Factors & ST & BC \\
\hline Working vol.(L) & 1.5 & 5 \\
\hline Height $\mathrm{a} /$ diameter & 0.5 & 3.9 \\
\hline GHSV $^{\mathrm{b}}$ in $\mathrm{h}^{-1}$ & 24 & 8.4 \\
\hline Mixer & Agitator & Ceramic membrane diffuser \\
\hline Mixing method & $200 \sim 600 \mathrm{rpm}$ & 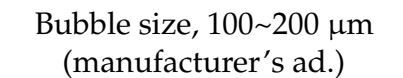 \\
\hline $\mathrm{pH}$ & $7.3 \pm 0.24$ & $7.2 \pm 0.26$ \\
\hline $\mathrm{NH}_{4}^{+}(\mathrm{mg} / \mathrm{L})$ & $915.2 \pm 323.8$ & $461.5 \pm 83.8$ \\
\hline Maximum O.D.600 nm & 16.2 & 12.5 \\
\hline $\mathrm{P}_{\mathrm{CH} 4, \max }$ in outflow ${ }^{\mathrm{c}}$ & $29.4 \%$ & $16.2 \%$ \\
\hline Maximum VVD ${ }^{d}$ & $77.8(\mathrm{VVD} / \mathrm{O} . \mathrm{D} .=4.8)$ & $19.8($ VVD/O.D. = 1.6) \\
\hline
\end{tabular}

${ }^{a}$ Working volume setting based. ${ }^{b}$ Gas hourly space velocity, inflow gas $\left(\mathrm{CO}_{2}: \mathrm{H}_{2}=1: 4\right)$ per working volume. ${ }^{\mathrm{c}}$ Maximum methane composition (\%) in outflow gas. ${ }^{\mathrm{d}}$ Volumetric production of methane per working volume per day. 
The characterization of the gas mass transfer is described by the volumetric mass transfer coefficient, which is dependent on various parameters, such as bioreactor design and operating conditions [32]. In detail, volumetric mass transfer was affected by changes in the stirrer speed and gas superficial velocity in the ST [33] and by the superficial gas velocity, the properties of the fluid and the geometric factors (height of the column, diameter of the column, and the sparger characteristics) in the BC [34]. Mass transfer between gas and liquid could be one of the main considerations in the design of biomethanation reactors. Microbubble generation (100-200 $\mu \mathrm{m}$ bubbles size advertised by the manufacturer) in the BC showed a comparable methane conversion rate with that in the ST operated with high agitation speed. This result suggested that microbubble generation could be used from an economic point perspective to increase the mass transfer depending on the reaction scale.

\subsection{Water Generation and Removal from Reactors}

Hydrogenotrophic methanation generates two moles of water during one mole of methane production as shown in Equation (1). Thus, the amounts of water generated daily can be calculated from methane production (Equation (4), using ideal gas volume, $22.4 \mathrm{~L} / \mathrm{mol}$ at STP, water density $1 \mathrm{~g} / \mathrm{mL}$, water molecular weight $18 \mathrm{~g} / \mathrm{mol}$ ).

$$
\begin{aligned}
\mathrm{H}_{2} \mathrm{O} \text { generation } & \left(\frac{\mathrm{mL}}{\mathrm{d}}\right) \\
= & \frac{\text { working vol. }(\mathrm{L}) \times \frac{\mathrm{CH}_{4} \text { vol. }(\mathrm{L})}{\text { working vol. }(\mathrm{L}) \cdot \text { day }}}{22.4 \mathrm{LCH}_{4} / 1 \mathrm{~mol} \mathrm{CH} \mathrm{H}_{4}} \times \frac{2 \mathrm{~mol} \mathrm{H}_{2} \mathrm{O}}{1 \mathrm{~mol} \mathrm{CH}_{4}} \times \frac{18 \mathrm{~g}}{1 \mathrm{~mol} \mathrm{H}_{2} \mathrm{O}} \\
& \times \frac{1 \mathrm{~mL} \mathrm{H}_{2} \mathrm{O}}{\mathrm{g} \mathrm{H}_{2} \mathrm{O}}=1.6 \times \text { working vol. }(\mathrm{L}) \times \mathrm{VVD} \cdot \frac{\mathrm{mL} \mathrm{H}_{2} \mathrm{O}}{\mathrm{L} \mathrm{CH}_{4}}
\end{aligned}
$$

Previous studies have reported water removal in chemical methanation processes using absorption on the catalyst [35] or adsorbent [36] (Sabatier process). On the other hand, during the microbial methanation process, the following two facts are inevitable: The active medium volume increases due to water generation from the methanation reaction and, consequently, the nutrient concentration utilized by methanogens for their growth and methane production decreases. Since severe nutrient dilution can occur due to water generation, except that utilized by methanogens, stable methanation performance requires the intermittent injections of concentrated nutrients and removal of generated water by pumps [30]. In particular, ammonium as the nitrogen source and sulfide to maintain redox potential should be sufficiently supplied for methanogen growth and methanation [37]. To remove only the generated water without discharging nutrients from the reactors, the MD process was integrated with the methanation process.

The water removal performance of MD in cell cultures was compared with that in the medium only. The membrane flux was $16.3 \pm 3.1 \mathrm{~L} / \mathrm{m}^{2} / \mathrm{h}$ and $19.2 \pm 3.3 \mathrm{~L} / \mathrm{m}^{2} / \mathrm{h}$, respectively (Figure 5). This value was higher than that in previous reports of $4.5 \sim 6 \mathrm{~L} / \mathrm{m}^{2} / \mathrm{h}$ using PVDF with the same temperature difference, $20^{\circ} \mathrm{C}$ vs. $60^{\circ} \mathrm{C}$ [38]. After operation, the membrane surface was visually checked and cell fouling was not significant, which seems to be due to low biomass ( 1.6 g MLVSS/L). 


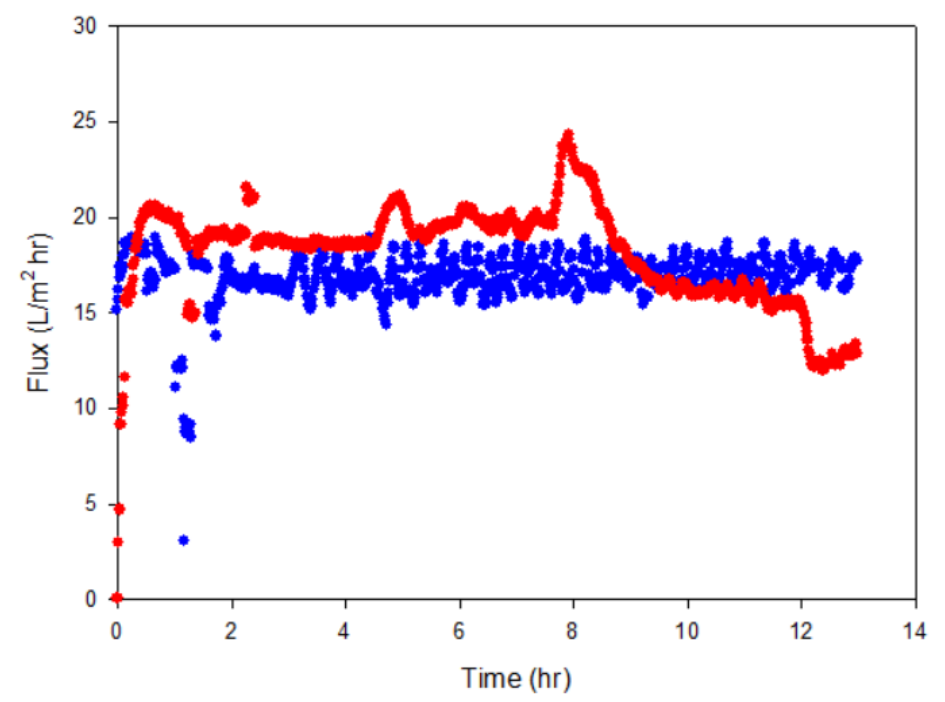

Figure 5. The membrane flux during water removal from the biomethanation process using membrane distillation (MD) with medium (blue line) and with cell culture (red line).

For hydrogenotrophic methanation, four moles of hydrogen are consumed to convert one mole of the $\mathrm{CO}_{2}$ into one mole of methane (Equation (1)). Four moles of hydrogen are equally divided into methane and water (Equation (1)). Thus, by using the water removed through the MD process for hydrogen production in an electrolyzer, water can be recycled, and the loss of hydrogen discarded as water can also be reduced. When small scale ex-situ biomethanation is built with a working volume of $120 \mathrm{~L}$ and a methane production rate of $400 \mathrm{VVD}$ (Figure 6), the amount of generated water was $3.2 \mathrm{~L} / \mathrm{h}$ (76.8 L/d), which was theoretically calculated as described in Equation (4). Based on our MD results, a membrane area of just $0.19 \mathrm{~m}^{2}$ is required, with an average water removal of $17 \mathrm{~L} / \mathrm{m}^{2} / \mathrm{h}$.

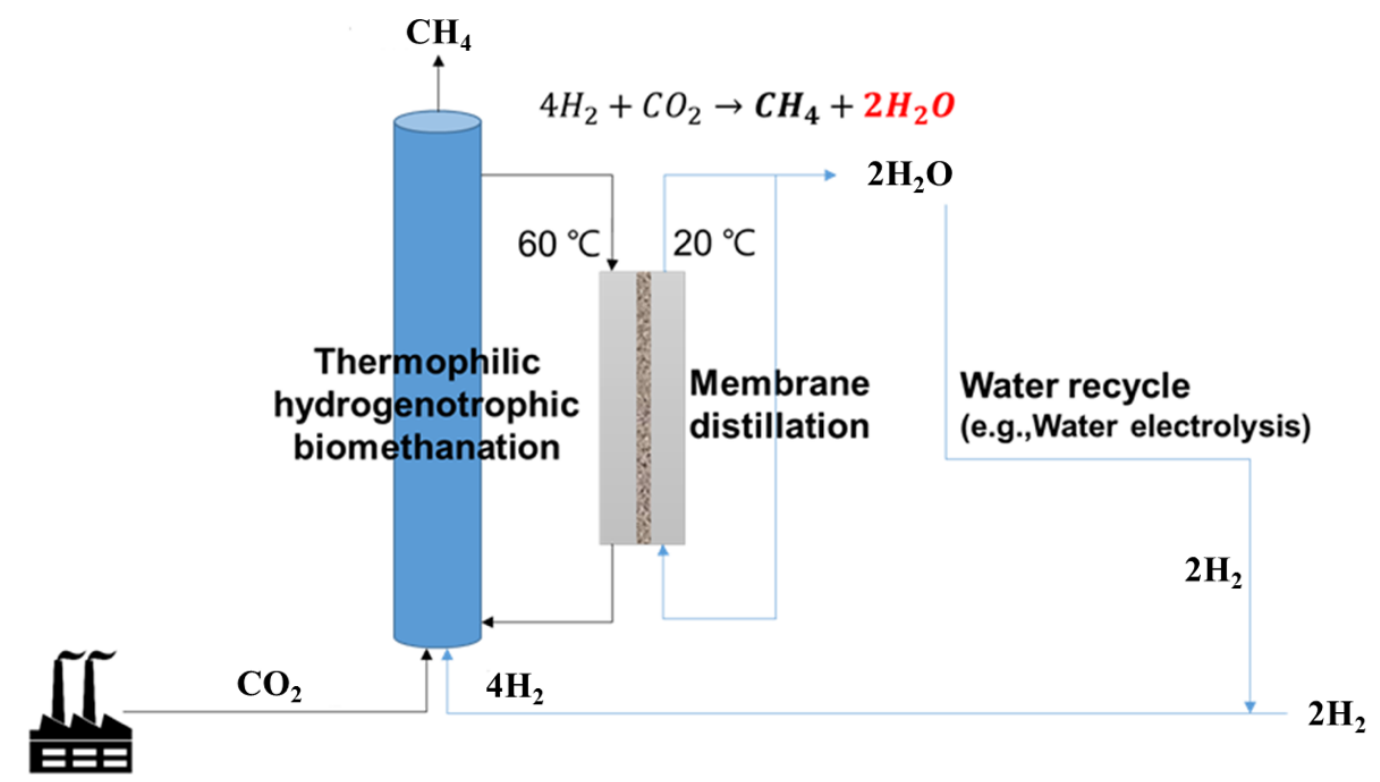

Figure 6. The biomethanation-membrane distillation combination process.

To ensure that only water was removed from the culture medium in the MD process, the conductivity and ammonium concentration were measured. The conductivity and total $\mathrm{N}$ in the feed of the MD process were $13 \sim 16 \mathrm{mS} / \mathrm{cm}$ and $260 \mathrm{mg} \mathrm{N} / \mathrm{L}$ at $1 \mathrm{~g} \mathrm{NH} \mathrm{NH}_{4} \mathrm{Cl}$, respectively. The conductivity in the permeate was approximately $1 / 1000$ of feed (up to $\sim 30 \mu \mathrm{S} / \mathrm{cm}$ ), and the total $\mathrm{N}$ was less than $5.5 \mathrm{mg} \mathrm{N} / \mathrm{L}$ (see Figure S1 in Supplementary Materials). These results indicate 
that only water was removed from the medium through MD and that most of the nutrients in the medium were left in the reactor and could be used to continuously maintain the activity of the methanogens. However, the total nitrogen (TN) increased as the experiments continued (Figure S1), indicating membrane pore wetting [39,40]. Long-term operation requires the study of cell fouling and wetting phenomena during membrane distillation. If water is discharged from the reactor due to the amount of water produced from methane production and is not removed through the MD, a high concentration of nitrous wastewater of about $1 \mathrm{~g} / \mathrm{L}$ is continuously generated and contained in the methanation reaction medium. By selectively removing only water from the methane reactor using $\mathrm{MD}$, it is possible to reduce the process installation and operating costs associated with treating high concentrations of nitrous wastewater. This cost reduction is another important advantage that can be obtained by integrating the MD process with a methanation reactor.

\section{Conclusions}

Biomethanation used in two types of reactors showed that a high agitation speed increased the methane conversion rate. The use of a microbubble generator in a cylinder type reactor showed a relatively stable methane conversion rate. It is reasonable to consider the application of microbubbles for biomethanation to enhance gas-liquid mass transfer. The use of MD for water removal from biomethanation can be a useful method to recover hydrogen present in water, i.e., half of the hydrogen used for biomethanation, and the use of MD can reduce the cost of wastewater treatment from biomethanation reactor discharge.

Supplementary Materials: The following are available online at http://www.mdpi.com/1996-1073/12/21/4130/s1, Figure S1: (a) Conductivity and (b) total nitrogen (TN) in the permeate.

Author Contributions: Data curation, M.K., B.K., Y.S., J.S.J., B.S.J. and B.-I.S.; Formal analysis, Y.G., Y.G.K. and B.-I.S.; Investigation, O.C.; Methodology, M.-G.H. and B.S.J.; Project administration, J.S.J.; Supervision, S.L. and B.-I.S.

Funding: This work was supported by the Korea Electric Power Research Institute (KEPRI, Korea) grant funded by the Korea Electric Power Corporation (KEPCO, Korea) (No. R17VA01), by the Korea Institute of Energy Technology Evaluation and Planning(KETEP) and the Ministry of Trade, Industry \& Energy(MOTIE) of the Republic of Korea (No. 2019281010007B), and by Hanyang University (HY-201100000000233-N).

Conflicts of Interest: The authors declare no conflict of interest.

\section{Abbreviations}

$\begin{array}{ll}\text { MD } & \text { Membrane distillation } \\ \text { ST } & \text { Stirred-tank reactor } \\ \text { BC } & \text { Bubble column } \\ \text { PVDF } & \text { Polyvinylidene fluoride } \\ \text { VSS } & \text { Volatile suspended solid } \\ \text { MLVSS } & \text { Mixed liquor volatile suspended solid } \\ \text { VVD } & \text { Methane volume per working volume per day, L/L/d } \\ \text { GHSV } & \text { Gas hourly space velocity }\end{array}$

\section{References}

1. Götz, M.; Lefebvre, J.; Mörs, F.; McDaniel Koch, A.; Graf, F.; Bajohr, S.; Reimert, R.; Kolb, T. Renewable Power-to-Gas: A technological and economic review. Renew. Energy 2016, 85, 1371-1390. [CrossRef]

2. Götz, M.; McDaniel Koch, A.; Graf, F. State of the art and perspectives of $\mathrm{CO}_{2}$ methanation process concepts for power-to-gas applications. In Proceedings of the International Gas Union Research Conference (IGRC), Copenhagen, Denmark, 17-19 September 2014.

3. Lindorfer, J.; Reiter, G.; Tichler, R.; Steinmüller, H. 14-Hydrogen fuel, fuel cells, and methane. In Managing Global Warming; Letcher, T.M., Ed.; Academic Press: Cambridge, MA, USA, 2019; pp. 419-453. [CrossRef] 
4. Ghaib, K.; Ben-Fares, F.-Z. Power-to-Methane: A state-of-the-art review. Renew. Sustain. Energy Rev. 2018, 81, 433-446. [CrossRef]

5. Taubner, R.S.; Schleper, C.; Firneis, M.G.; Rittmann, S.K. Assessing the ecophysiology of methanogens in the context of recent astrobiological and planetological studies. Life 2015, 5, 1652-1686. [CrossRef] [PubMed]

6. Pan, X.; Angelidaki, I.; Alvarado-Morales, M.; Liu, H.; Liu, Y.; Huang, X.; Zhu, G. Methane production from formate, acetate and $\mathrm{H}_{2} / \mathrm{CO}_{2}$; focusing on kinetics and microbial characterization. Bioresour. Technol. 2016, 218, 796-806. [CrossRef]

7. Jabłoński, S.; Rodowicz, P.; Łukaszewicz, M. Methanogenic archaea database containing physiological and biochemical characteristics. Int. J. Syst. Evol. Microbiol. 2015, 65, 1360-1368. [CrossRef]

8. Nishimura, N.; Kitaura, S.; Mimura, A.; Takahara, Y. Growth of thermophilic methanogen KN-15 on $\mathrm{H}_{2}-\mathrm{CO}_{2}$ under batch and continuous conditions. J. Ferment. Bioeng. 1991, 72, 280-284. [CrossRef]

9. Nishimura, N.; Kitaura, S.; Mimura, A.; Takahara, Y. Cultivation of thermophilic methanogen KN-15 on $\mathrm{H}_{2}-\mathrm{CO}_{2}$ under pressurized conditions. J. Ferment. Bioeng. 1992, 73, 477-480. [CrossRef]

10. Peillex, J.-P.; Fardeau, M.-L.; Belaich, J.-P. Growth of Methanobacterium thermoautotrophicum on on hydrogen-carbon dioxide: High methane productivities in continuous culture. Biomass 1990, 21, 315-321. [CrossRef]

11. Alitalo, A.; Niskanen, M.; Aura, E. Biocatalytic methanation of hydrogen and carbon dioxide in a fixed bed bioreactor. Bioresour. Technol. 2015, 196, 600-605. [CrossRef]

12. Burkhardt, M.; Busch, G. Methanation of hydrogen and carbon dioxide. Appl. Energy 2013, 111, 74-79. [CrossRef]

13. Dupnock, T.L.; Deshusses, M.A. High-performance biogas upgrading using a biotrickling filter and hydrogenotrophic methanogens. Appl. Biochem. Biotechnol. 2017, 183, 488-502. [CrossRef] [PubMed]

14. Jee, H.S.; Yano, T.; Nishio, N.; Nagai, S. Biomethanation of $\mathrm{H}_{2}$ and $\mathrm{CO}_{2}$ by Methanobacterium thermoautotrophicum in membrane and ceramic bioreactors. J. Ferment. Technol. 1987, 65, 413-418. [CrossRef]

15. Karadagli, F.; Rittmann, B.E. Thermodynamic and kinetic analysis of the $\mathrm{H}_{2}$ threshold for Methanobacterium bryantii MoH. Biodegradation 2007, 18, 439-452. [CrossRef] [PubMed]

16. Lee, J.C.; Kim, J.H.; Chang, W.S.; Pak, D. Biological conversion of $\mathrm{CO}_{2}$ to $\mathrm{CH}_{4}$ using hydrogenotrophic methanogen in a fixed bed reactor. J. Chem. Technol. Biotechnol. 2012, 87, 844-847. [CrossRef]

17. Rittmann, S.; Seifert, A.; Herwig, C. Quantitative analysis of media dilution rate effects on Methanothermobacter marburgensis grown in continuous culture on $\mathrm{H}_{2}$ and $\mathrm{CO}_{2}$. Biomass Bioenergy 2012, 36, 293-301. [CrossRef]

18. Schill, N.; Van Gulik, W.; Voisard, D.; Von Stockar, U. Continuous cultures limited by a gaseous substrate: Development of a simple, unstructured mathematical model and experimental verification with Methanobacterium thermoautotrophicum. Biotechnol. Bioeng. 1996, 51, 645-658. [CrossRef]

19. Thauer, R.K.; Kaster, A.-K.; Seedorf, H.; Buckel, W.; Hedderich, R. Methanogenic archaea: Ecologically relevant differences in energy conservation. Nat. Rev. Microbiol. 2008, 6, 579. [CrossRef]

20. Alklaibi, A.M.; Lior, N. Membrane-distillation desalination: Status and potential. Desalination 2005, 171, 111-131. [CrossRef]

21. Hsu, S.T.; Cheng, K.T.; Chiou, J.S. Seawater desalination by direct contact membrane distillation. Desalination 2002, 143, 279-287. [CrossRef]

22. Warsinger, D.M.; Swaminathan, J.; Guillen-Burrieza, E.; Arafat, H.A.; Lienhard, V.J.H. Scaling and fouling in membrane distillation for desalination applications: A review. Desalination 2015, 356, 294-313. [CrossRef]

23. Gryta, M.; Tomaszewska, M.; Karakulski, K. Wastewater treatment by membrane distillation. Desalination 2006, 198, 67-73. [CrossRef]

24. El-Abbassi, A.; Hafidi, A.; Khayet, M.; García-Payo, M. Integrated direct contact membrane distillation for olive mill wastewater treatment. Desalination 2013, 323, 31-38. [CrossRef]

25. Gryta, M.; Tomaszewska, M.; Grzechulska, J.; Morawski, A. Membrane distillation of $\mathrm{NaCl}$ solution containing natural organic matter. J. Membr. Sci. 2001, 181, 279-287. [CrossRef]

26. Alkhudhiri, A.; Darwish, N.; Hilal, N. Membrane distillation: A comprehensive review. Desalination 2012, 287, 2-18. [CrossRef]

27. Park, S.-M.; Lee, S. Influence of Hydraulic Pressure on Performance Deterioration of Direct Contact Membrane Distillation (DCMD) Process. Membranes (Basel) 2019, 9, 37. [CrossRef] [PubMed] 
28. Cho, H.; Choi, Y.-J.; Lee, S.; Koo, J.; Huang, T. Comparison of hollow fiber membranes in direct contact and air gap membrane distillation (MD). Desalin. Water Treat. 2016, 57, 10012-10019. [CrossRef]

29. Liu, Y.; Wang, Y.; Wen, X.; Shimizu, K.; Lei, Z.; Kobayashi, M.; Zhang, Z.; Sumi, I.; Yao, Y.; Mogi, Y. Enhanced bioconversion of hydrogen and carbon dioxide to methane using a micro-nano sparger system: Mass balance and energy consumption. RSC Adv. 2018, 8, 26488-26496. [CrossRef]

30. Martin, M.R.; Fornero, J.J.; Stark, R.; Mets, L.; Angenent, L.T. A single-culture bioprocess of Methanothermobacter thermautotrophicus to upgrade digester biogas by $\mathrm{CO}_{2}$-to- $\mathrm{CH}_{4}$ Conversion with $\mathrm{H}_{2}$. Archaea 2013, 2013, 11. [CrossRef]

31. Seifert, A.H.; Rittmann, S.; Herwig, C. Analysis of process related factors to increase volumetric productivity and quality of biomethane with Methanothermobacter marburgensis. Appl. Energy 2014, 132, 155-162. [CrossRef]

32. Braga, A.; Mesquita, D.P.; Amaral, A.L.; Ferreira, E.C.; Belo, I. Aroma production by Yarrowia lipolytica in airlift and stirred tank bioreactors: Differences in yeast metabolism and morphology. Biochem. Eng. J. 2015, 93, 55-62. [CrossRef]

33. Garcia-Ochoa, F.; Gomez, E. Prediction of gas-liquid mass transfer coefficient in sparged stirred tank bioreactors. Biotechnol. Bioeng. 2005, 92, 761-772. [CrossRef] [PubMed]

34. Garcia-Ochoa, F.; Gomez, E. Bioreactor scale-up and oxygen transfer rate in microbial processes: An overview. Biotechnol. Adv. 2009, 27, 153-176. [CrossRef] [PubMed]

35. Borgschulte, A.; Gallandat, N.; Probst, B.; Suter, R.; Callini, E.; Ferri, D.; Arroyo, Y.; Erni, R.; Geerlings, H.; Züttel, A. Sorption enhanced $\mathrm{CO}_{2}$ methanation. Phys. Chem. Chem. Phys. 2013, 15, 9620-9625. [CrossRef] [PubMed]

36. Walspurger, S.; Elzinga, G.D.; Dijkstra, J.W.; Sarić, M.; Haije, W.G. Sorption enhanced methanation for substitute natural gas production: Experimental results and thermodynamic considerations. Chem. Eng. J. 2014, 242, 379-386. [CrossRef]

37. Gerhard, E.; Butsch, B.M.; Marison, I.W.; von Stockar, U. Improved growth and methane production conditions for Methanobacterium thermoautotrophicum. Appl. Microbiol. Biotechnol. 1993, 40, 432-437. [CrossRef]

38. Macedonio, F.; Ali, A.; Poerio, T.; El-Sayed, E.; Drioli, E.; Abdel-Jawad, M. Direct contact membrane distillation for treatment of oilfield produced water. Sep. Purif. Technol. 2014, 126, 69-81. [CrossRef]

39. Goh, S.; Zhang, J.; Liu, Y.; Fane, A.G. Fouling and wetting in membrane distillation (MD) and MD-bioreactor (MDBR) for wastewater reclamation. Desalination 2013, 323, 39-47. [CrossRef]

40. Rezaei, M.; Warsinger, D.M.; Duke, M.C.; Matsuura, T.; Samhaber, W.M. Wetting phenomena in membrane distillation: Mechanisms, reversal, and prevention. Water Res. 2018, 139, 329-352. [CrossRef] 